\title{
Confession Validity in Civil Right in Iranian Law and International Conventions
}

\author{
Behnam Khodadoost ${ }^{1} \&$ Seyed Mahmoud Mirkhalili ${ }^{2}$ \\ ${ }^{1}$ Department of Criminal Law and Criminology, College of Law Saveh, Science and Research Branch Islamic \\ Azad University, Saveh, Iran \\ ${ }^{2}$ Assistant Professor in Pardis Farabi of Tehran university, Lector in Faculty of Law, Science and Research \\ University, Saveh Branch, Saveh, Iran \\ Corespondance: Behnam Khodadoost, Department of Criminal Law and Criminology, College of Law Saveh, \\ Science and Research Branch Islamic Azad University, Saveh, Iran. Tel: 98-93-6129-1639. E-mail: \\ Khodadoost.behnam@gmail.com
}

Received: January 13, 2016 Accepted: March 10, 2016 Online Published: April 27, 2016

doi:10.5539/jpl.v9n3p55 URL: http://dx.doi.org/10.5539/jpl.v9n3p55

\begin{abstract}
Confession importance in retribution and even in civil affairs is so that law scientists call it as key reasons. Its importance is that is always in claims such as the most important reason to it. In principal in punishment affairs, confession accused without there is investigation on his/her validity confession and there is documentaries on its affirm, there is not subjectivism and maybe there is from knowledge and presumption from court located on accused crime identification, therefore there is not worth confession that it obtains from compulsion, threat and torment and it has no way to it and taking confession to this way is perfect breach for civil law in law examination. There is one of sensible antitype retribution justice, observe civil law in judgmental courts there is the most important pillar in observation civil right, security and freedom in judgement sessions and especially confession controversy is the same subject. Guarantee civil law and judgement execution all of judgement procedures including crime discovery, pursuit, investigation, punishment execution or security and cultivation actions are basic assignments of retribution justice. In this study there was paid to specify confession place in judgements and volume its credit with confirm on civil rights.
\end{abstract}

Keywords: confession, retribution judgment, civil right confession validity

\section{Introduction}

Obtain reason is the radial law subjects and especially retribution justice. We examine two subjects in obtain reason, first there are using reasons such as tool and affirmation resource or ascribe, are there observe lawful in obtain that items? In other words, is there including validity principle for obtain reason or not? Second, has been gathered reasons in legal way, could be ascribe crime to accused man in standard way? It is maybe judge ascribe crime to accused man with regard to documents and circumstances, but this judgment breach in order lack of reason sufficiency in resource. (Farakhsheh, 2014).

There is one of the most tension controversial subjects in every court is confession from everybody for his/her tort and/or testimonial against other man. Whether there is order his/her intake rights or other's right confirms or override in court. Confession and testimony subjects in law rules and of course more seriously in retribution problems is focus from law and attorney. From civil right aspect in third edition of civil law means claim affirmation reasons subject, it was paid to confession in civil claims in first book and there was paid to attention to conditions and results of confession. There was subject in 168 and 169 articles of Islamic punishment law: « (168) article- there is pervasive confession that confessor is to be wise, full grown, peon and free during confession. (169) article- the confession that obtained under mandatory, torment and/or physical or mental tease, has not credit and worth and court should re-investigation from accused man again.»

Therefore there are the most important points in confession about judge that have perfect and expanded attention is validation confession conditions. Authority and intention are basic pillars in everybody that without those there is not created any retribution responsibility in minimal according Islamic punishment law for actual everybody. What more sentences in right courts are issue according testimonial . 


\section{Citizenship Concept}

Citizenship concept in social dimension was idea that born in west in Europe and has been published simultaneous with expanding in $16^{\text {th }}$ century. Accept laws and legal and political duties due to citizenship place is basic and substantial idea this concept.

Political identity, loyalty to political geographic territory, respect to law, careful attention to other's rights and is being to know to privileges and its altitude and finally obey from duties are due to citizenship and enjoying from citizenship right that was created citizen concept in nowadays meaning .

In 14 clause of constitution third principium has been specified to «supply full perfect rights including woman and man and square judgmental security» for all of people and «public equality against law». Return to past of laws (169 principium), acquaintance principium (37 principium), Judgmental supply principium (32 principium) using of attorney right principium (35 principium), and prohibition torment and obtain confession with threat principium (38 principium) aboveboard judgement (165 principium) and compliance given principium (34 principium) are including citizenship rights that has been considered in constitution of Islamic republic in Iran.

\section{Confession Concept and Its Elements and Conditions}

Confession is that proving action with his/her saying in word, expressing word in explicit and obvious manner and in term in general there is news and express right for other profit and against self in retribution law that often using for accept execution crime by accused man.

\subsection{Elements Confession Definition}

News: there is kind of news, mean from past till now or informing for future a kind of something and confessor informs he/she has right for another man to him/her.

Else profit: third element "being profit for else one. Non including actual or legal person and even there is confession to action that is pensionable Islamic punishment or excuse punishment, although this kind is not profit for else other man, but we could know it this kind of confession for profit society with some neglect.

Confessor loss: confession must pensionable induct loss and stroke to physical body (in retribution law) and/or harm or damage to financial cattle (confessor). Therefore if confession has not harm for confessor and has other harm it is considered as testimony.

\subsection{Confession Pillars}

1) Confessor or domicile

2) Beneficiary from confession or domicile

3) Confession subject or in domicile

4) Concubine or confession word

\subsection{Domicile Conditions}

1) Maturity: confession from individuals are less than 18 years old is not incisive, although they confession.

2) Wise: confessor should to be wise therefore confession from madman is not incisive. If confessor to be period madman and he/she does confession in mental health and lack of madness this kind of confession is incisive.

3) Growth: confession from daffy men is not effective; of course confession from daffy men is incisive at affairs that are financial. For example, confession daffy man to execution crime that has Islamic punishment or nemesis or excuse punishment such as adultery or accusing man to adultery or buggery is effective.

4) Intention: confessor has intension for informing during confession and words and actions that are accomplish without intention has not legal effect, then confession man is not effective during sleep, unintelligent or in drunken.

5) Authority: confessor should have authority and has not mandatory for it .

\section{Basic Validity and Augment Confession}

We refer to 1258 clause civil law in beginning that in first its clause has been considered confession from proving reasons for claims meanwhile confession definition has been mentioned in 1259 clause: «confession is that right informs for else one and in loss for self» although confession manner is extensive and general because 
according 1260 clause civil law «confession accomplish for every word that implies to it» word every saying in this clause is absolute law it is including every kind of saying for confession although confession should to be explicit and clear.

Because there was mentioned on 1268 clause in civil law «suspected confession is not effective» but whole of proven and denies in confession subject are about confession validity. There was mentioned on (168) clause in Islamic punishment law: «confession is effective that confessor to be wise, mature, peon and free during confession» therefore there are important points that we consider to it with perfect and extended attention about judge, are confession conditions. Authority and intention are two basic pillars in every confession that without two them there is not created retribution responsibility at minimal according Islamic punishment law for any legal person. Whatever many of sentences in right courts are issue according testimony, but is there everybody could testimony with every condition and in every situation for every subject? Exactly no, testimonial has other conditions than domicile (confessor). According (177) clause Islamic punishment law «legal testimonial should have these conditions during testimony: a- maturity, b- wise, c- faith, $d$ - justice, e- purity, f- not beneficial at subject, g-not having hostility with parties or one of them, h- not occupant in pauperize, i- not to be tramper.» so that with attention to these conditions judge could issue sentence according testimonies whatever after being these mentioned conditions again testimonial should attest for proving his/her loyalty .

\section{Confession Validity in Retribution Affairs}

Mean of «else» are one or another men except confessor (domicile).

Mean of « on loss self» it means on confessor. It is better to explain it, informing subjects that we are saying or Have informing aspect and they were considered in ordinary talks or therein to law claim and retribution dossier. First kind is not related to out subject but second kind has three situations:

a- We declare a thing to benefit for another man and loss self that is confession.

b- We declare a thing on benefit self and other loss that is claim

c- We declare a thing on other benefit and another man loss that is testimony or evidence.

According 38 principium at constitution «there is forbidden every kind torment for taking confession and/or obtain information, there is forbidden to constraint to testimony or oath and this kind of testimony or confession and oath has not validity and credibility, offender from this legal principium has punishment.

The important point in this retribution confession is different than civil confession, according 360 clauses of retribution judgmental law related to 2014 , «whenever accused man confession to his/her crime exactly, so that there is no doubt and misgiving in confession and also doubt in validity and authority for it, the court is issue sentence according this confession»

\section{Forbidden Torment}

Some of Islamic lawyers have been explained torment including every kind tease and torment and there is separator between torment and tease and harassment that is continuity for tease and pain in torment. So that Tousi sheikh explained torment in this way:

Torment, is obtain harassment for its owner and this torment is continues for that one.

With deduction to nowadays rules it is could definite torment in this way: every kind of tease and physical harassment that governmental agents or official and public authority owners do those actions during their duties or according their job for taking confession from accused man. Of course in this definition, mental pillar for torment was limited to taking confession from accused man .

In constitution that other rules are to be coincident with it in (38) principium self to affirmation confession sentence due to torment and mentions it: constraint person to testimony, oath or confession is not permissible and this testimony and confession and oath has not credit and value. Offender from this principium has punishment according law. This principium absolutely and without any exception, it declared forbidden every kind torment including physical or mental and with any tool and at every way with perfect precision and it is not credit. Following this following legal principium, it declares confession sentence due to torment:

The 9 clause of constitution considered respect to legal freedoms and maintain civil rights: every kind of torment accused man for taking confession and/or constraint him/her to other affairs are forbidden and these confessions have not legal argument.

The 4 clause forbidden torment law: whole of confessions and admissions that took without observing these clauses related to this law and accused man denies those, if there are not reasons and acceptable documents, has 
not validity and those are not valid.

In convention torment forbidden, this convention knows torment as privative civil and social rights and definite that in this way:

First clause: this convection definite torment in this way: every action that accomplish due to pain or intense physical and mental harassment against person for obtain information or taking confession from him/her or third party it calls torment. (also) torment a person such as action that he/she or third party has been executed and/or it is likely he/she executes, with threat and constraint and according discrimination in every kind and when this harassment and tease and/or with in provocation and stimulus and/or with satisfaction and lack of resistance governmental agent and/or other authority owner first ranked person is considered as torment.

\section{Reasons for Validity Confession}

\subsection{Holy Quran}

There is predicting verses from holy Quran for validity confession that we are referring to that in following:

\section{First verse}

(AL emran, 81 verse) (remembering that when the god got seriously treaty from messengers and their followers) that whenever I gave to you holy Quran and science, then the messenger who came to you that who confirms whatever I gave you, faith to and help him, then (god) said to them: do confession to this subject and contract seriously to that?

They said (yes) we confession, (god told them) (on this treaty) to be witness, I am witness together you.

In this verse, god got confession from people that treaty and promise that they accepted ordered treaty and promise and then put on this promise self and those angels on this confession. However we could conclude from this verse that god put people for accepting their promise and answerable to their treaty and its results due to acceptance, but we conclude anther point from this verse that god considered confessions people to acceptance obligations due to their treaty with self as validity and tool for proving their possibility breaching treaty.

\section{Second verse}

(Toubeh, 102 verse) and some of them has confession to their sin (concision) that did good and bad actions, we are hoping that god accept their sin that of course god is forgiving and kind. In this verse some of Arab people confession to their sin and their actions are mixed good and bad actions and from this point they hope to forgiving their sin from god and this verse express this situation (Tafsir al-mizan, 1996, p.376).

\subsection{Tradition}

In controversy from documents for confession in tradition and holy prophet method and stories and news from holy messengers to this following, there has been argument for validity confession:

Mohammad Ibn Yaghob is one of our friends ... he is one of surgeon and one of son of abi adeallah (greeting to him) said: I don't accept testimony of lecher man unless to his/her tongue». Argument aspect is that lecher is not accepting his/her testimony against another man for lack of justice. Therefore accepting his/her testimony against self is ignorance of testimony reasons and we should searching another basic for his/her testimony validity against self and this affair is not possible unless we know it including confession and validity base. In other word, correct testimony of lecher man against self is to depend on acceptance lecher individuals against self.

\subsection{Consensus}

One of reasons that was predict for validity confession on it, consensus Islam lawyers on validity this base (Tousi, 2000, p.3) (Javaher al-kalam, 1989, p.3) (Riaz al-masael, 2015, p.238) (Ibn roshd, p.471) but with attention to text, we could not to consensus as independent reason for argument in other word consensus is document and it has not validity.

\subsection{The Wise Men Method}

The wise men from a nation with attention to culture level and thinking and their civilization and without considering religious and way and their thinking religious, they believe on whole of items that confession of every wise intentioned and independent man against his/her loss self is valid and obligatory. In addition the judge has denied this way and it is enough for validity confession. Even some of authors go beyond this limit and they know validity and importance confession from a wise man against self is necessary sentence from all of religious and nations. 


\section{Compulsion to Confession, Wastage of Citizenship Right}

In rules of citizenship right, there was emphasis on observing perfect rights on investigations and forbidden torment and harassment for confession to crime. Judge should not compulsion accused man to ignorance when he/she want to gathering reasons and crime documents for completing dossier, it is mean he/she should not put $\mathrm{him} / \mathrm{her}$ in horrible space than he/she does confession because constitution says agents should say to accused man why arresting him/her and he/she knows what does he/she do. According 1277 clause civil law, this is confession that is done from fun, kidding and/or compliment. In other word we could say that in exactly in all of items that it is obvious that the domicile has no intention and satisfaction, it causes confession is not valid. Also confession from ignorance to subject or sentence caused confession has not validity basic conditions and it could not has validity .

From Islam retribution punishment even if crime could not discovered and accused man remains without punishment, it is better that accused man did confession because he/she has afraid and in result lack of knowing to his/her right and/or under pressure and he/she punishment. Accused man has silence right and Islam gave this right to him/her that could silent against questions, it is obvious that Islam has more attention to rights and citizenship freedom for every individuals and it not to emphasis to proving all of crime certainly and all of criminals receive punishment. Wastage accused man right, torment, to put pressure accused man for confession to crime, compulsion to confession and doing illegal actions for proving and discovery crime, are items that in constitution, citizenship rights, human rights and human conventions and citizenship and Islamic sentences has emphasis to illegal and its forbidden and there was mentioned as the most important breach items for citizenship right for individuals in judgements and wastage accused man rights and observing square investigation and judgment.

\section{Common Points for Lawmaker in Iran, $U N$ and EU}

1) Forbidden using of torment and punishment for accused man principle

2) Not validity for inputs as result of obtain with torment

3) Using of possibility ways for preventing and fighting with torment

4) Training executive governmental agents and supervision on their behaviors

5) Torment definition and its pillar and elements, it is obvious consensus for them as mental and physical pillar of torment. Purposely hurt and severe mental- spiritual torment and interference governmental agents as material pillar and obtain reason or intimidation and severely punishment accused man as mental pillar is including this treaty.

6) Removing hurt from torment about balance judgmental trend with UN and human rights resources is necessary mention, although it is not denied that there are deficiencies in judgmental laws and rules and judgmental department with helping parliament and state should employing with seriously and attempt human rights despite insular of some of persons in perfect supply in rights and freedoms, but news associations, state with approach expanded improves in recent years than meanwhile making clearance Islamic republic of Iran position against important subjects about human rights, civil and political right for citizens than supply it in favorite.

Forbidden torment convention and other behaviors and cruelly punishments and non-human behaviors confirmed public association of UN and (39.46) article at 10 December 2006 in three sections and including 33 articles that provide substantial approaches for states for preventing torment.

\section{Citizenship Observing Right in Iran and International Conventions}

International treaty for civil and political right in 9 clause declares it is not arrested anyone headstrong or detained that person, it is not foreclose freedom from anyone unless according aspects and judgmental rules considered to constitution. According statue of international retribution punishment, suspected person to commitment one of crimes under authority judgmental, bureau has right for informed before investigation during trial a reason on to be criminal or considered as his/her innocence, right of enjoying of legal assistances and investigation right at especial attorney unless that criminal has ignored from this right. According 69 clause statues, breaching these procedures causes, bureau not including reasons those obtained result of torment from reasons category. Decisions related to constitution, urgent receive right and immediately information related to reasons for arresting and charges are subjected to him/her and trial right without delay are rights for suspected who has considered statue of crime.

Suspected person has right to refer to unaligned judgmental authority for re-investigation to necessary or lack of 
necessary detain. This is same affair that at common love and to compliance right according calling detainee arrangement. According one of accepted and proven principals in human rights international rules, detain before trial, when it not exceeds limit rational time, it is permissible law .

Assumption innocence accused man when his/her commitment not proven, it constitutes base and foundation retribution judgmental trend, therefore unduly delay in investigation and/or justifiable detain for suspected, is bullet that targeting heart of judgmental trend. Human rights American convention has mentioned similar rules to 7 clause and African charter for human has referred to necessaries in 6 clause too.

\section{In Iranian Law}

Constitution in Iran in principals, was expressed dominant rules on pursuit accused men and in 32 principal was considered « it is not arrested anybody unless the law defines its arrangements, if the person was arrested charge subject should signification to him/her immediately in write and he/she should recognize it in maximal time in 24 hours preliminary dossier is sending to judgmental resources and trial arrangements, is providing immediately. Offender from this principal according law has punishment». 35 principal of constitutions declares «in every courts, parties have right to choose attorneys» and according 38 principal forbidden torment and confession to force were considered on one of innocence principal in pursuit procedure.

According 129 clause constitution of Islamic republic of Iran, judge should investigate identity of accused man and important specification and also home address exactly so that signification and summons and other documents is to be easily and it was mentioned that accused man should careful about saying and then he/she realizes accused charges and its reasons in exactly to accused man. Whenever investigations are begins. Questions should obvious and clear. Induce questions, cheating, reluctance or compulsion to accused man is forbidden. So that accused man refuses from answering, his/her refuse was written in process verbal. Objection right for accused man to detain arrangement was inserted at (33) clause and investigation of review court will be out of alteration. Anyway accused situation should be clear at one month.

Respect rule to legal freedoms and maintain citizenship rights has been paid to some of dominant basics rules on investigation and pursuit procedure. According one clause this clause, pursuit crimes and investigations and issue security arrangements and temporary detain should to be obvious and clear according to observing rules with judgmental sentence and order and it is avoid from execution personal styles and abusive from power and/or execution violence and/or additional detains and without necessity. In arresting and investigation or wanting information and investigation, it is avoid from tease individuals such as closing eye and other organs, letdown and lowering to them. According (7) clause all of investigators and investigation agents should avoid to cover face accused man or sit behind him/her or taking them to invisible places and in general illegal actions. According 9 clause unity article there is forbidden every kind torment for taking confession from accused man and/or compulsion him/her to another actions and takin confessions have not validity legal. Also all of investigations and examinations, should to be according legal practical procedures and previous trainings and under necessary supervision and when individuals ignore these rules and arrangements and resort to illegal methods for execution their duties, we have to pursuit them according considered law (10 clause)

\section{In International and Regional Documents}

The 10 clause of human international act, was considered audit right to individuals claims by independent and unaligned court in fairly and aboveboard and declares these courts could take decision about retribution charge for individuals. Also according 11 clause of this act, audit to public claim and charge of individuals should execution with observation whole of necessary securities for defense. Also nobody for doing or not doing that during commitment that action according national or international rights is not crime, has not trial .

Also European convention supporting of human right and substantial freedoms in (6) clause has referred to these securities and also it is 8 clause of human rights American convention has confirmed fairly judge as one of important results of innocence principle. also human rights African charter some of judge principles including defense right, trial right during rational period time at independent court, lawsuit right in authority national resources has included in (7) clause.

International retribution bureau statue in (67) clause, at especial dominant principles on fairly judge, accused man has right for every charge that has trial in aboveboard, fairly and unaligned and with observation following these considerations in equal:

a- In language that accused man understanding it and speaks in that language, he/she should to be informed from nature, cause and content of charge immediately and exactly. 
b- Court should give time and necessary possibilities for defending him/her and could communicate freely and in secret with attorney that chosen.

c- Accused man should not have trial without unjustifiable delay.

d- With observation 2 clause of 63 article and for defending, attendants in court and/or via chosen judgmental counselor and informed that if not enjoying of judgmental counselor, he/she has right for enjoying from judgmental counselor that statue provides for him/her in necessity and in straightforward justice execution, even have not financial power for paying related expenses for that.

e- He/she could ask questions from witnesses himself/herself or by another one that whom were introduced against him/her and according same conditions that those witnesses had against himself/herself ask related witnesses to himself/herself have attendance in court session and ask them questions.

f- If investigations of court and/or the documents are offering in trial is in another language that accused man speaks it, he/she could enjoying from skilled translator freely and also the translated documents that it is necessary offering at court sessions.

g- Accused man not has to testimony and/or confession to his/her crime and could to be silent without his/her silence was considered as confession or deny.

h- $\mathrm{He} / \mathrm{she}$ could offer written bill or verbal statements without he/she oath.

i- There is not force to mutual task for proving reasons and/or denies those on accused man.

\section{Discussion}

According justify principle, maintain social security and observe plaintiff rights and accused man are considered important principles in retribution judgement and attempt in realization social justice and guarding it is necessary on judgmental department. Creating equilibrium between necessity pursuit criminal and observe rights and protection human munificence of accused man is necessary related to judgmental department.

1) Observing judgmental rights of accused man in discovery crime, preliminary investigations from judgmental department.

2) Being enough executive securities due to breach citizenship right of individuals in judgmental procedures.

3) Forbidden torment and compulsion and threat, tease and non-human punishment execution for taking confession and protection validity for individuals and prevent from issuing unjust trials.

4) Careful and continuous supervision on judgmental procedures with appointment unaligned and informed supervisors on trials affairs.

5) Enjoying defense securities, necessity credit and human prestige related to accused men and necessity recovery comer losses on innocent detainees with emphasis on citizenship rights rules.

6) Removing legal gaps, meanwhile supervision on wellness execution being rules and basic revise with emphasis on religious judgment on Islamic judgmental department.

\section{References}

Civil law of Islamic republic of Iran.

Constitution of Islamic republic of Iran.

Crianghsagh, G. S. (2005). International retribution law. Translator: Yousefian, B., \& Esmaili, M., Tehran, Samt Publication.

Ebadi, S. (2008). History and human rights documents in Iran. Roshangharan Publication.

Holy Quran.

Human rights international act. (1948).

Ibn Roshd. (1409). bedayeh al-mojtahed and nehayed al-moghtased, taha edition, Abdolraoof, Saad, Beirut, 2 edition

International retribution bureau statue.

Islamic punishment law. (2014).

Respect rule on legal freedoms and protection citizenship rights. 
Retribution investigation law. (2014).

Shabath, W. (2006). Introduce on international retribution bureau. Translator: Seyed Bagher Mir Abbasi and Hamid Alhoyi Nazari, Tehran, Jungle Publication.

Shayeghan, F., Tarom Seri, M., Gholshan Pajoh, M., Mostaghimi, B., \& Moulaei, Y. (2004). Enforcing international cooperation on human rights ground. Gherayesh Publication.

Tabatabei, M. H. (1996). Tafsir al-mizan (9nd ed.). Translator: Mousavi, M.B., Publisher: Islamic publication office Society of Seminary Teachers of Qom.

Tamoshot, C. (2008). Human rights. translation of Hosseini Sharifi Tarar Kohi, Mizan Publication.

Toosi (Sheikh Toosi), ibn Hassan, M., al-mabsouth, gh. (2000). maktabeh Motazavieh (3rd ed.). Tehran, Iran.

\section{Copyrights}

Copyright for this article is retained by the author(s), with first publication rights granted to the journal.

This is an open-access article distributed under the terms and conditions of the Creative Commons Attribution license (http://creativecommons.org/licenses/by/3.0/). 